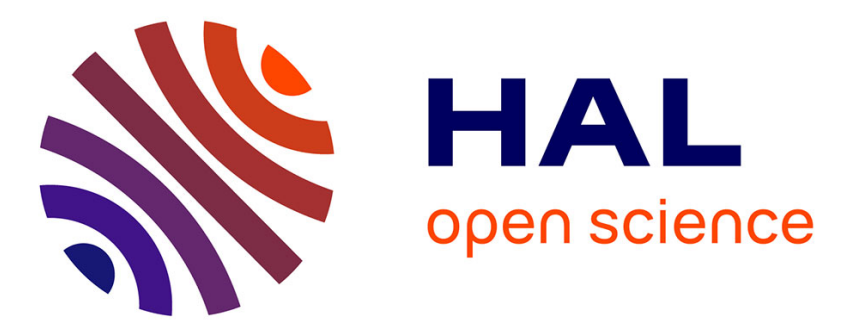

\title{
Antibacterial, anti-adherent and cytotoxic activities of surfactin(s) from a lipolytic strain Bacillus safensis F4
}

Faten Abdelli, Marwa Jardak, Jihene Elloumi, Didier Stien, Slim Cherif, Sami Mnif, Sami Aifa

\section{- To cite this version:}

Faten Abdelli, Marwa Jardak, Jihene Elloumi, Didier Stien, Slim Cherif, et al.. Antibacterial, antiadherent and cytotoxic activities of surfactin(s) from a lipolytic strain Bacillus safensis F4. Biodegradation, In press, 10.1007/s10532-018-09865-4 . hal-02093931

\section{HAL Id: hal-02093931 \\ https://hal.sorbonne-universite.fr/hal-02093931}

Submitted on 9 Apr 2019

HAL is a multi-disciplinary open access archive for the deposit and dissemination of scientific research documents, whether they are published or not. The documents may come from teaching and research institutions in France or abroad, or from public or private research centers.
L'archive ouverte pluridisciplinaire HAL, est destinée au dépôt et à la diffusion de documents scientifiques de niveau recherche, publiés ou non, émanant des établissements d'enseignement et de recherche français ou étrangers, des laboratoires publics ou privés. 


\section{Antibacterial, anti-adherent and cytotoxic activities of $\operatorname{surfactin}(\mathbf{s})$}

$4{ }^{1}$ Faten ABDELLI, ${ }^{1}$ Marwa JARDAK, ${ }^{1}$ Jihene ELLOUMI, ${ }^{2}$ Didier STIEN, ${ }^{3}$ Slim CHERIF, $5 \quad{ }^{1}$ Sami MNIF and ${ }^{1 *}$ Sami AIFA

6

7

8

9

${ }^{1}$ Laboratory of Molecular and Cellular Screening Processes, Centre of Biotechnology of Sfax, P.O. Box 1177, 3018

${ }^{2}$ UPMC UNIV PARIS 06, CNRS, Laboratoire de Biodiversité et Biotechnologies Microbiennes (LBBM), Sorbonne Universities, Observatoire Oceanologique, 66650 BanyulsSur-Mer, FRANCE.

${ }^{3}$ Faculty of Sciences, Gafsa. University Campus Sidi Ahmed Zarrouk 2112 Gafsa. University of Gafsa.

*Corresponding author:

Prof. Sami Aifa

Centre of Biotechnology of Sfax (University of Sfax).

Sidi Mansour Road Km 6, BP 1177, 3018 Sfax, Tunisia

Email : $\underline{\text { sami.aifa@cbs.rnrt.tn }}$

Phone: +216-74871816

Fax: $+216-74875818$ 


\section{Abstract}

The bacterial strain F4, isolated from olive oil-contaminated soil, has been found to produce biosurfactants as confirmed by oil displacement test and the emulsification index results. The identification of the strain $\mathrm{F} 4$, by $16 \mathrm{~S}$ ribosomal RNA gene, showed a close similarity to Bacillus safensis, therefore the strain has been termed Bacillus safensis $\mathrm{F} 4$. The Thin Layer Chromatography (TLC) and the High Pressure LiquidChromatography-Mass Spectrometry (HPLC-MS/MS) demonstrated that the biosurfactant had a lipopeptide structure and was classified as surfactin. The present study showed also that the produced biosurfactant has an important antibacterial activity against several pathogen strains as monitored with minimum inhibitory concentration (MIC) micro-assays. In particular, it presented an interesting antiplanktonic activity with a MIC of $6.25 \mathrm{mg} \mathrm{mL}^{-1}$ and anti-adhesive activity which exceeded 80\%against the biofilm-forming Staphylococcus epidermidis S61 strain. Moreover, the produced lipopeptide showed an antitumor activity against T47D breast cancer cells and B16F10 mouse melanoma cells with $\mathrm{IC}_{50}$ of $0.66 \mathrm{mg} \mathrm{mL}^{-1}$ and $1.17 \mathrm{mg} \mathrm{mL}^{-1}$, respectively. Thus, our results demonstrated that Bacillus safensis F4 biosurfactant exhibited a polyvalent activity via a considerableantibiofilm and antitumoralpotencies.

\section{Keywords:}

Anti-adherent; anti-cancer; Biosurfactant; Bacillussafensis F4; Surfactin(s). 


\section{Introduction}

Biosurfactants or bioemulsifiers are amphipathic surface-active molecules, which are produced by micro-organisms, composed of hydrophobic (nonpolar) and hydrophilic (polar) moieties. As aconsequence, theyhave the ability to aggregate at interfaces between fluids with different polarities such as oil/water or air/water, reducethe surface and interfacial tensions and form emulsions (Sen et al. 2017). These compounds are characterized as glycolipids, lipopeptides, lipopolysaccharides, fatty acids, phospholipids and neutral lipids (Bezza and Chirwa2016; Collaet al. 2010). Biosurfactantsare produced by a wide variety of bacteria, actinobacteria and fungi with different chemical structures. Some bacterial genera like Bacillus and Arthrobacterare known with their production oflipopeptidebiosurfactant (Sriram et al. 2011).Somestudies have described the biological activities of the biosurfactants including antimicrobial, anti-adhesive and anti-biofilm properties (Silva et al. 2014, Gudiña et al. 2010a).In fact, the bacterial infections and their biofilm formation abilities causing resistance increase against drugs is getting a serious problem for human health. An urgent need for solving this problem is based on the screening of novel drugs eradicating or inhibiting biofilm formation. The adherence is the first step of the infectious process that requires efficient antagonising molecules. Previous studies reported that based on their amphiphilic structures, the biosurfactants reduce the surface tension and therefore affecting the bacterial adherence (Janek et al. 2013).In this context, the lipopeptidebiosurfactant produced by Bacillus subtilis presented antibacterial, anti-adhesive and anti-biofilm activities on uropathogenic bacteria (Moryl et al.2015).Moreover, a glycolipid biosurfactant, presented cytotoxic activities on cancer cell lines, was produced by a Nocardiafarcinica strain(Christova et al. 2015). The biosurfactants, which are selective in nature, act on the surface of liquids and facilitate the action of certain enzymes such as lipases and/or esterasesby reducing the surface 
tension of liquids and/or improving the solubility of water immiscible substrates (Sekhon et al. 2011, 2012).

Lipases are characterized by their ability to synthesize ester bonds in a non-aqueous media (Ülker and Karaoglu 2012) and their production can be associated with several factors including $\mathrm{pH}$, temperature, carbon source and the presence of inducers such as oils and some biosurfactants (Cherif et al. 2011; Colla et al. 2010).

Nowadays, biosurfactants take an important scientific interest with their interesting proprieties such as the high biodegradability, lower toxicity, better environmental compatibility, and important specific activity at extreme conditions of temperature, $\mathrm{pH}$ and salinity (Sriram et al. 2011).

In this context, searching for novel biosurfactant producing strains with potential biosurfactant production is required. For that,lipolytic strains could be a possible original source of biosurfactant production (Sekhon et al. 2012).The present study describes the biosurfactant production by a lipolytic strain B.safensisF4 and investigatesits antibacterial, anti-adhesive and antitumor activities.

\section{Materials and methods}

\section{Bacterial strains}

B. safensis F4, B. subtilis,Staphylococcus aureus, Enterococcus faecium,Micrococcus luteus,Agrobacterium tumefaciens, Salmonella enterica, Escherichia coli and Pseudomonas savastanoiweregrown in LB (Luria-Bertani) medium.S. epidermidis S61, abiofilm-forming bacterium isolatedin our lab from the roof of an old house in Sfax, Tunisia(Jardak et al. 2017), was grown in Tryptic Soy Broth (TSB) medium. 
Breast cancer T47D and mouse melanoma B16F10 cell lines, obtained from the American

Type Culture Collection (ATCC), were grown in Dulbecco's modified Eagle's medium

(DMEM) supplemented with $10 \%$ foetal bovine serum, $50 \mathrm{IU} / \mathrm{mL}$ penicillin, $50 \mathrm{mg} \mathrm{mL}$ -

${ }^{1}$ streptomycin at $37^{\circ} \mathrm{C}$ in a humidified $5 \% \mathrm{CO}_{2}$ atmosphere.

\section{Bacterial biosurfactantactivity}

107

The oil displacement assay was performed according to Morikawa et al. (1993)using the Petri plate (90 mm diameter) filled with $25 \mathrm{~mL}$ of distilled water then $10 \mu \mathrm{L}$ of a crude oil was added. $10 \mu \mathrm{L}$ of a cell free culture supernatant was slowly placed on the center of the oil surface. The diameter of the clear halo zone was measured after 30 seconds of incubation.

The determination of the emulsification index (E24) is carried out according to the following equation(Cooper and Goldenberg 1987).E24 was measured using the cell free culture. Two millilitres of a vegetable oil were added to an equal volume of cell free supernatant and homogenized for 2 minutes at high speed. The height of emulsion layer was measured after 24h.All the experiments were done in triplicate.

$$
\text { E24 }(\%)=(\text { Total height of the emulsified layer / Total height of the liquid layer }) \times 100
$$

\section{Surface tension determination}

Surface tension of the $24 \mathrm{~h}$ culture broth supernatant was measured according to the De Nouy methodology using a tensiometer TD1 (Lauda-K“"onigshofen, Germany). The measurement was performed in triplicate.

\section{Identification of bacterial strain}

Strain F4 was identified using the API 20E test Enterobacteriacae(BioMérieux, France) and by sequencing of the $16 \mathrm{~S}$ rRNA gene. The genomic DNA of the strain F4 was extracted 
following the protocol detailed by Wilson et al. (1987). The 16S ribosomal DNA of the strain F4 was amplified by PCR (Polymerase chain reaction) using the universal bacterial primers Fd1 and Rd1 (Fd1， 5'-AGAGTTTGATCCTGGCTCAG-3'; Rd1， 5'-AAGGAGGTGATCCAGCC-3'), and the following program: denaturation at $94^{\circ} \mathrm{C}$ for $30 \mathrm{sec}$, annealing at $55^{\circ} \mathrm{C}$ for $45 \mathrm{sec}$ and extension at $72^{\circ} \mathrm{C}$ for $1 \mathrm{~min} 45 \mathrm{sec}$ for a total of 30 cycles.

The PCR products were purified with a Favor Prep GEL/ PCR Purification Kit (FAVORGEN) and sequenced using the ABI PRISM, 3100.The obtained sequences were compared with other bacterial sequences in the NCBI database using BLAST program. The phylogenetic tree was constructed using the neighbour-joining method (Naruya and Nei 1987) by MEGA 4.0.

\section{Bacterial biosurfactant production}

B.safensisF4 strain was retained as the best local strain producing biosurfactant. The strain was incubated overnight at $30^{\circ} \mathrm{C}$ and $160 \mathrm{rpm}$ in $250 \mathrm{~mL}$ shaking flasks with $100 \mathrm{mLof} \mathrm{LB}$ medium. Two millilitres of culture were used as inoculum and were cultivated in $500 \mathrm{~mL}$ shaking flasks containing $200 \mathrm{~mL}$ of the medium with $1 \%$ olive oil. The culture was incubated for $24 \mathrm{~h}$ at $180 \mathrm{rpm}$ and $30^{\circ} \mathrm{C}$ to allow maximum biosurfactant production. Cellfree supernatant was obtained by centrifugation at $4^{\circ} \mathrm{C}$ during $20 \mathrm{~min}$ at $4000 \mathrm{xg}$ (ROTANTA $460 \mathrm{RF}$, Hettich). The obtained supernatant was treated by acidification to $\mathrm{pH} 2.0$ using a3M $\mathrm{HCl}$ solution and incubated overnight at $4^{\circ} \mathrm{C}$. Then, the acidified supernatant was extracted with ethyl acetate and concentrated with a rotary evaporator (Gargouri et al. 2016).

\section{Thin layer chromatography (TLC)}

The extracted biosurfactant in ethyl acetate was analysed by TLC. The sample dissolved in methanol was spotted on silica gel TLC plate (TLC Silica gel $60 \mathrm{~F}_{254}$, Merck Darmstadt, Germany). The plate was developed with a mobile phase of chloroform/methanol/water 
respectively in the ratio of 65:25:4 (v/v/v). The dried plate was sprayed with a solution of $0.25 \%$ ninhydrin in acetone and then, incubated at $105^{\circ} \mathrm{C}$ for $5 \mathrm{~min}$ (Janek et al. 2010).

\section{Biosurfactantpurification and identification}

The extracted biosurfactant in ethyl acetate was fractioned using solid-phase extraction (SPE) (Alajlani et al. 2016). $\mathrm{C}_{18}$ Phenomenex strata-X column (silica gel, $10 \mathrm{~g}$ ) was conditioned by the elution of 3 volumes of acetonitrile. The sample was deposited on the surface of the silica and drawn through the solvent. For the mobile phase, the HPLC (High Pressure Liquid Chromatography) grade acetonitrile (100\% - 3 volume column) was used in first step, then a binary mixture of HPLC grade dichloromethane/ methanol (v/v - 3 volume column) was used. The obtained eluates were collected and dried under vacuum. Finally, the acetonitrilefraction was retained.

Two microliters of acetonitrile fraction diluted at $5 \mathrm{mgmL}^{-1}$ in methanol, were injected in a Dionex Ultimate 3000 UHPLC-HESI HRMS Q-Exactive focus system (Thermo Scientific) connected to Xcalibur software. The chromatographic separation was conducted followed the protocol of Girard et al. (2017) with slight modifications. TheHypersil GOLD $\mathrm{C}_{18}$ column $(150 \mathrm{~mm} \times 2.1 \mathrm{~mm})$ with $1.9 \mu \mathrm{m}$ particle size (Thermo Scientific) and constant flow rate of $0.5 \mathrm{~mL} \mathrm{~min}{ }^{-1}$. The column oven was set to $50^{\circ} \mathrm{C}$. The water (eluent $\mathrm{A}$ ) and acetonitrile (eluent B) containing both $0.1 \%$ formic acid, were used as mobile phases. A gradient profile was applied, starting with $5 \%$ of B and kept constant for $1 \mathrm{~min}$. The percentage of B was linearly increased to $100 \%$ in $15 \mathrm{~min}$, and was kept at $100 \%$ for $9 \mathrm{~min}$ and returned to initial conditions over $1 \mathrm{~min}$. Four minutes of equilibration were followed, giving a total operating time of 30 min. The instrument has been run in the full scan mode with a range of 100 to $1500 \mathrm{~m} / \mathrm{z}$ equipped with an electrospray interface (ESI). The polarity of the electrospray interface was continuously switched between positive and negative polarity. The LB medium 
was used as a control subjected to extraction with ethyl acetate. The common peaks between the chromatographs of the samples and the medium were not retained.

\section{Determination of minimum inhibitory concentration (MIC)}

The minimum inhibitory concentration (MIC) for the lipopeptide, produced by B.safensis F4, was defined as the lowest concentration that inhibited the growth of microorganisms after 24 h. The test was performed against several human and plant pathogenicstrains (S.aureus, E.faecium, M. luteus, A. tumefaciens, S. enterica, E. coli and P. savastanoi) and B. subtilis. The choice of these strains is justified since we tried to maximize our chance for finding interesting molecules that could be applied to fight against human or plant bacterial infections. The biosurfactant anti-planktonic activity against $S$. epidermidis S61 was performed with the same test. Each bacterium was grown in $\mathrm{LB}$ medium overnight at $30^{\circ} \mathrm{C}$. Bacterial cultures were then adjusted to an optical density of 0.6 at a wavelength of 600 $\mathrm{nm}$. The crude biosurfactant was dissolved in Dimethylsulfoxide (DMSO) and then filtered. Serial dilutions were made to yield volumes of $100 \mu \mathrm{L}$ per well with final concentrations ranging from 0.0125 to $25 \mathrm{mg} \mathrm{mL}^{-1}$ in $\mathrm{LB}$ medium. Twenty microliters of bacteriumovernight culture, with appropriate OD, wereadded to each well and a final volume of $200 \mu \mathrm{L}$ per well was adjusted with medium. Wells containing just LB medium with inoculum and these containing medium, inoculum and Ampicillin served as controls. The plate was then incubated at $37^{\circ} \mathrm{C}$ for $24 \mathrm{~h}$. Twenty microliters of MTT (3-(4,5-dimethylthiazol-2-yl)-2,5diphenyltetrazolium bromide) solution at $1 \mathrm{mg} \mathrm{mL}^{-1}$ were added to each well.

The determination of the biosurfactant MICwas based on the MTT color change.In fact, the viable bacteria were detected by the change of yellow MTT color to purple. For that, the well devoid of bacterial growth(yellow color) was retained as MIC, which was expressed in mg $\mathrm{mL}^{-1}$.The same test was carried out against Gram-positive and Gram-negative strains. 


\section{Anti-adhesive activity}

198

199

200

201

202

203

204

205

206

207

208

209

210

211

212

213

214

215

216 217 (Thermofisher).

The 96-well flat bottom plates were used for biofilm cultures (Mathur et al. 2006).

S. epidermidis S61, a biofilm-forming strain (Jardak et al. 2017), was grown overnight in TSB medium at $30^{\circ} \mathrm{C}$ and diluted with fresh medium supplemented with $2.25 \%(\mathrm{w} / \mathrm{v})$ glucose.One hundred microliters of the bacterial culture dilution was added into each well to obtain a final $\mathrm{OD}_{600 \mathrm{~nm}}$ of 0.1 . Then, $100 \mu \mathrm{L}$ of B.safensisF4biosurfactant dissolved in TSB, containing $20 \%$ (v/v) ofDMSO, at various concentrations, were added into wells to reach final concentrations of $0.039,0.078,0.156,0.312,0.625,1.25,2.5,5$ and $10 \mathrm{mg} \mathrm{mL}^{-1}$. Wells containing onlyTSB medium supplemented with, 2.25\% glucose and $20 \%(\mathrm{v} / \mathrm{v})$ of DMSO, and bacterial suspension were served as controls.

Plates were incubated for $24 \mathrm{~h}$ at $30^{\circ} \mathrm{C}$ under static conditions. After incubation, the wells were emptied into a container by inverting the plates. Each well was gently washed twice with $250 \mu \mathrm{L}$ of sterile phosphate buffered saline (PBS: $137 \mathrm{mMNaCl}, 2.7 \mathrm{mM} \mathrm{KCl} ; 10 \mathrm{mM}$ $\mathrm{Na}_{2} \mathrm{HPO}_{4} ; 1.76 \mathrm{mM} \mathrm{KH} \mathrm{PO}_{4} ; \mathrm{pH}$ 7.2) in order to remove the planktonic cells (Beenken et al. 2003) . After washing, plates were dried at $60^{\circ} \mathrm{C}$ for $60 \mathrm{~min}$. Then, wells were stained with $150 \mu \mathrm{L}$ of crystal violet $(0.2 \%)$ prepared in $20 \%$ ethanol for $15 \mathrm{~min}$ at room temperature(Vasudevanet al. 2003). After staining incubation, crystal violet was removed and excess dye was washed three times with sterile water. Finally, $200 \mu \mathrm{L}$ of glacial acetic acid $33 \%$ was added to each well and plates were incubated for 1 hour at room temperature. The optical density (OD) was measured at $570 \mathrm{~nm}$ using a Varioskanmicroplate reader

The percentage of the adhesion inhibition wascalculated by the following formula:

[(OD (control*) - OD (treated strain) ) / OD (control*) $)$ x 100

*Control: untreated strain with the extract 
The anti-adhesive activities of the crude biosurfactant and the acetonitrilefraction, against $S$. epidermidisS61 were confirmed by microscopic observations using the OLYMPUS fluorescent microscope BX50 equipped with a digital camera OLYMPUS DP70. The biofilms were grown on glass pieces $(\varnothing 10 \mathrm{~mm})$ placed in 24 -well polystyrene plates treated with the biosurfactant.Non-treated wells, containing TSB supplemented with $10 \%(\mathrm{v} / \mathrm{v})$ of DMSO, served as controls (Padmavathi and Pandian 2014).The biosurfactant was added at a final concentration of $10 \mathrm{mg} \mathrm{mL}^{-1}$ in TSB with $10 \%$ (v/v) of DMSO. The bacterial inoculation was adjusted toan $\mathrm{OD}_{600 \mathrm{~nm}}$ of 0.1 . Plates were incubated at $30^{\circ} \mathrm{C}$ for $24 \mathrm{~h}$. The wells were then carefully emptied with pipetting and glass slides were washed with sterile PBS (1X) before the treatment with $500 \mu \mathrm{L}$ of acridine orange $(0.1 \%$, w/v, dissolved in PBS1X). Visualization was performed througha 40x objective using U-MWB2 filter with excitation at 460-490 nm and emission at $520 \mathrm{~nm}$.

\section{Cytotoxicity assays}

T47D breast cancer and B16F10 mouse melanoma cells were grown in 96-well plates (Orange Scientific) until $40 \%$ confluence. Thebiosurfactant, wasadded at different concentrations $\left(0.1,1\right.$ and $\left.10 \mathrm{mg} \mathrm{mL}^{-1}\right)$ and incubated for 48 hours at $37^{\circ} \mathrm{C}$ in a humidified atmosphere containing $5 \% \mathrm{CO}_{2}$.

The cell viability was assessed using the MTT assay as previously described by Mosmann (1983).After treatment, the medium was exchanged by a fresh one and $10 \mu \mathrm{L}$ of MTT solution $\left(5 \mathrm{mg} \mathrm{mL}^{-1}\right.$ in PBS) were added. After incubation for 4 hours, $100 \mu \mathrm{L}$ of $10 \%$ SDS (Sodium dodecyl sulfate) solution were added to each well to dissolve the formazan. The optical density was measured at $570 \mathrm{~nm}$ using a Varioskanmicroplate reader (Thermofisher). The growth inhibition was expressed according to the following formula:

$$
(\%) \text { cell survival }=(\mathrm{AT} / \mathrm{A} 0) \times 100
$$


A0: control absorbance; AT: treated cells absorbance.

\section{StatisticalAnalysis}

All experimentsweredone in triplicate. The obtainedresults are expressed as mean values with the standard error. The statistical analyses wereperformedusingStudent's t-test to compare the controls and treatedsamples at a significancelevel of $5 \%$.

\section{Results and discussion}

\section{Selection of biosurfactant producing strain}

Morphological and biochemical tests showed that the rod-shaped strain F4 was motile, Grampositive, catalase-positive and oxidase-positive. Based on the phylogenetic analysis of the 16S rRNA gene sequences, the strain F4 was affiliated to the genus Bacillus with $99 \%$ of similarity to Bacillus safensis FO-36b ${ }^{\mathrm{T}}$ (AF234854) (Fig. 1)and was termed as B. safensis F4.The 16S rRNA gene sequence, including 1378 nucleotides, was deposited in the GenBank nucleotide database under the accession number MF927780.

In fact, B.safensisF4 was retained after laboratory screening of lipolyticstrainsfor their ability to produce biosurfactant during growth on olive oil. The oil displacement assay showed that the selected strain presented the highest clear halo zone (about $21.08 \pm 1.46 \mathrm{~cm}^{2}$ ). The emulsification activity of the selected strain against sunflower oil was $74.99 \%$. Previous results showed that Bacillus cereus NK1 biosurfactant presented a clear halo zone of $2.95 \mathrm{~cm}^{2}$ and $62 \%$ in the oil displacement test and emulsification activity against $n$-hexadecane, respectively(Sriram et al. 2011).Ibrahim (2018) claimed that biosurfactant produced by Ochrobactrumanthropi HM-1 culture showed a clear halo zone $38.5 \mathrm{~cm}^{2}$, while $33.17 \mathrm{~cm}^{2}$ was presented by Citrobacterfreundii HM-2 biosurfactant. The cell-free culture broths of 
HM-1 and HM-2 strains successfully emulsified sunflower oil with approximately $70 \%$ and $60 \%$, respectively.

\section{Surface tension determination}

Surface tension is a key parameter for the evaluation of biosurfactant production.In fact, a microorganism is considered as a promising biosurfactant producer, if it could reduce the surface tension to less than $40 \mathrm{mN} \mathrm{m}^{-1}$ (Shete et al., 2006). The obtained results showed that our biosurfactant is able to reduce surface tension until $30.73 \mathrm{mN} \mathrm{m}^{-1} \pm 0.48$ which is lower than results obtained by Ghazala et al.(2017) during the characterization of an anionic lipopeptide produced by Bacillus mojavensis I4 where the surface tension of the culture supernatant was $31.5 \pm 0.8 \mathrm{mN} \mathrm{m}^{-1}$.Moreover, our results are very close to those obtained by Jemil et al., (2016) which showed that the best result in decreasing surface tension was observed with Bacillus methylotrophicusDCS1 strain $\left(31 \mathrm{mN} \mathrm{m}^{-1}\right)$.Likewise, other study showed that biosurfactants produced by O.anthropi HM-1 and C.freundii HM-2 were able to reduce surface tension until $30.8 \pm 0.6$ and $32.5 \pm 1.3 \mathrm{mNm}^{-1}$, respectively (Ibrahim 2018).While, compared to surface tensions of some chemical surfactants studied by Ghazala et al. (2017), B.safensisF4 cell free broth showed lower surface tension than SDS $\left(34.8 \pm 1.3 \mathrm{mN} \mathrm{m}^{-1}\right)$ and Triton $\mathrm{X}-100\left(32 \pm 0.9 \mathrm{mN} \mathrm{m}^{-1}\right)$.

\section{Characterization of B.safensisF4 biosurfactant}

TLC analysis showed that $B$. safensis F4 biosurfactant is a lipopeptide. Therelative front $\left(\mathrm{R}_{\mathrm{f}}\right)$ value was 0.56 (Fig. 2) which confirmed that the biosurfactant extract is a lipopeptide as reported by similar previous studies (Fernandes et al. 2007).

In order to identify our biosurfactant, the acetonitrile fraction was collected, and then analysedby LC-MS (Liquid chromatography-mass spectrometry) (Fig. 3). The details of the 
obtained masses have been identified according to previous reported studies. Results showed the presence of two surfactinderivates $\left(\mathrm{M}+\mathrm{H}^{+}=1022.6668\right.$ and $1008.6513 / \mathrm{M}-\mathrm{H}+=1020.6579$ and 1006.6436, respectively) at retention time of $15.98 \mathrm{~min}$ with the presence of adducts $(\mathrm{M}+\mathrm{Na})$ (Table 2). The presence of surfactin was confirmed by the positive and negative ionizationmode (Jasim et al. 2016). At the same retention time of $15.98 \mathrm{~min}$, the two compounds were identified as Leu/Ile-7, $\mathrm{C}_{14}$ surfactin and Leu/Ile-7, $\mathrm{C}_{13}$ surfactin with different masses of $1021.66 \mathrm{~m} / \mathrm{z}$ and $1007.65 \mathrm{~m} / \mathrm{z}$ (Price et al. 2007). Another peak at 9.20 min has been depicted $\left(\mathrm{M}-\mathrm{H}^{+}=329.2328\right)$, which could correspond to pinellic acid. According to literature, pinellic acid is mainly known with its anti-allergic (Arulselvan et al. 2016) and anti-inflammatory (Nagai et al. 2004) activities.

\section{Determination of minimum inhibitory concentration (MIC)}

Das et al. (2008) reported that some types of biosurfactants produced by many Bacillusspecies present antimicrobial activity against many bacteria including pathogenic strains.

Our lipopeptide showed limited activity against Gram-negative bacteria compared to that obtained against the Gram-positive tested strains. The tested biosurfactant has a MICof 0.78 $\mathrm{mg} \mathrm{mL} \mathrm{m}^{-1}$ against B. subtilisand $1.56 \mathrm{mg} \mathrm{mL}^{-1}$ against $S$. aureus, E. faecium and M. luteus. However, it presented a MIC value of $3.125 \mathrm{mg} \mathrm{mL}^{-1}$ against A. tumefaciens, S. enterica, E. coli and $1.56 \mathrm{mg} \mathrm{mL}^{-1}$ against P.savastanoi(Table 1).Moreover, Singh andCameotra (2004) reported that the lipopeptide produced by $B$. subtilis $\mathrm{C} 1$ was found to be active against several Gram-positive bacteria.

In another study, biosurfactant produced by the Lactobacillus paracasei ssp. paracasei A20 showed significant antimicrobial activities against pathogenic E. coli, S.aureus with MIChigher valuesranging between 25 and $50 \mathrm{mg} \mathrm{mL}^{-1}$ comparing with our results (Gudiña et al. 2010 b).Likewise, a high level of growth inhibition was observed against different 
pathogens with a biosurfactant produced by Lactobacillus helveticusat a concentration of 25 $\mathrm{mg} \mathrm{mL} \mathrm{m}^{-1}$ (Sharmaand Saharan 2016). Furthermore, many lipopetides produced by Bacillus licheniformis, (Yakimov et al. 2007; Fiechteer 1992) and B. subtilis (Vollenbroich et al. 1997) were known by their important antimicrobial activities. In other studies, the crude biosurfactant produced by Lactobacillus jensenii presented approximately $100 \%$ activity against $E$. coli, and $S$. aureus with a MIC of $50 \mathrm{mg} \mathrm{mL}^{-1}$ which are higher than our MICvalues (Sambanthamoorthy et al. 2014).

Concerning the anti-planktonic activity, the crude biosurfactant and the acetonitrile fraction were tested against S. epidermidis S61.Results showed that the crude biosurfactant and acetonitrile fraction effectively inhibited its growth with MIC of $12.5 \mathrm{mg} \mathrm{mL}^{-1}$ and $6.25 \mathrm{mg}$ $\mathrm{mL}^{-1}$, respectively. However, biosurfactantproduced by L.helveticus showed a high percentage of growth inhibition (98.4\%) against S. epidermidis with a concentration of $25 \mathrm{mg}$ $\mathrm{mL}^{-1}$ (Sharma and Saharan 2016).

\section{Anti-adhesive activity}

The ability of the crude biosurfactant and the acetonitrile fraction to inhibit the early biofilm formation at various concentrations was carried out against S. epidermidisS61. According to the Figure 4 , the crude biosurfactant and the tested fractionsignificantly $(P<0.001)$ inhibited the biofilm formation with approximately the same percentages of $90 \%$ and $80 \%$ at the concentrations of 10 and $5 \mathrm{mg} \mathrm{mL}^{-1}$,respectively. However, at the concentration of $2.5 \mathrm{mg}$ $\mathrm{mL}^{-1}$, the acetonitrile fraction, containing the surfactin, showedhigher anti-adherence activity with a percentage of inhibition of $64 \%$ against $53 \%$ of the crude biosurfactant.Comparing with our results, the purified biosurfactant produced by $B$. cereus NK1 presented lower percentagesof biofilm inhibition of S. epidermidis at the raison of $33.55 \%$ and $26.46 \%$ at concentrations of 10 and $5 \mathrm{mg} \mathrm{mL}^{-1}$, respectively(Sriram et al. 2011).In similar studies, the 
anti-adhesive activity of B.methylotrophicus DCS1 crudelipopeptide was evaluatedagainst different strains usingbiosurfactant pre-treated polystyrene surfaces. Results showed that the highest anti-adhesive effect was observed against $C$. albicans with an inhibition percentage of about $89.3 \%$ when biosurfactant was applied at a concentration of $1 \mathrm{mg} \mathrm{mL}^{-1}$ (Jemil et al., 2017).In another study, the crude biosurfactant isolated from L. paracasei ssp. paracasei A20 inhibited the adherence of $S$. epidermidis at the concentration of $50 \mathrm{mg} \mathrm{mL}^{-1}$ with a percentage of $72.9 \%$ (Gudiña et al. 2010 b) compared to 90 and $80 \%$ at 10 and $5 \mathrm{mg} \mathrm{mL}^{-1}$ respectively of our present biosurfactant.

Moreover, biosurfactant produced by L. helveticus showeda potential anti adhesive activityagainst S.epidermidiswith a percentage of $85 \%$ which is similar to our results but at higher concentration of $25 \mathrm{mg} \mathrm{mL}^{-1}$ (Sharma and Saharan 2016).Furthermore, biosurfactants produced byL. jensenii and L. rhamnosus presented anti-adhesive and anti-biofilm activities against the pathogen strains A. baumannii, E. coli, and S. aureus at concentrations ranging between 25 and $50 \mathrm{mg} \mathrm{mL}^{-1}$ (Sambanthamoorthy et al. 2014).

The anti-adherence activity of the two extracts was confirmed by fluorescence microscopy. The images of the acridine orange staining treated slides with extractsshowed the reduction in 356 the biofilm covered surface compared to the control (Fig. 5). Lipopeptides are able to 357 decrease biofilm surface and interfacial tension (Zhao et al. 2017). Previous studies demonstrated that biosurfactants had the ability to alter the surface characteristics of bacterial cells and reduce their adhesive properties. In fact, the application ofbiosurfactantto a 360 substratum surface can decrease its hydrophobicity, interfere with the microbial adhesion and microorganisms adsorption process (Rodrigues et al. 2006a).

\section{Cytotoxicity assays}


The cytotoxicity assay of the crude biosurfactantand the acetonitrile fraction was performed against T47D breast cancer cells and B16F10 mouse melanoma cells.

Figures 6 showed that the crude biosurfactant and the acetonitrile fraction showed high inhibition against T47D and B16F10 cells at $10 \mathrm{mg} \mathrm{mL}^{-1}(P<0.001)$. Furthermore, at the concentration of $1 \mathrm{mg} \mathrm{mL}^{-1}$, the acetonitrile fraction was more toxic against B16F10 cells with a survival of $59.75 \%$ than T47D cells, whereas, at concentration of the $0.1 \mathrm{mg} \mathrm{mL}^{-1}$, both tested samples did not show any toxicity against both cell lines.

The acetonitrile fraction inhibited significantly cancer cell growth at almost all the tested concentrations $(P<0.01)$.It presented an $\mathrm{IC}_{50}$ of $1.17 \mathrm{mg} \mathrm{mL} \mathrm{m}^{-1}$ and $0.66 \mathrm{mg} \mathrm{mL} \mathrm{m}^{-1}$ against B16F10 cells and T47D cells, respectively (Fig. 7).

These results can be correlated with the composition of the acetonitrile fraction, which mainly consists of surfactin, belonging to lipopeptides. According to literature, lipopeptides can act as antitumor agents (Rodrigues et al. 2006b).

Previous studies reported that a biosurfactant extracted from Lactobacillus caseishowed antiproliferative potencies against an epithelial cell line with an $\mathrm{IC}_{50}$ (The half-maximal inhibitory concentration) ranging from $109.1 \pm 0.84 \mathrm{mg} \mathrm{mL}^{-1}$ to $129.7 \pm 0.52 \mathrm{mg} \mathrm{mL}^{-1}$ (Merghni et al. 2017)which are higher than the $\mathrm{IC}_{50}$ values obtained by our biosurfactant.

Moreover, it was previously demonstrated that surfactin could disrupt the membrane structure via two main mechanisms which are insertion into lipid bilayers, modification of membrane permeabilization via channel formation or diffusion of ions across the membrane barrier and membrane solubilization by a detergent-like mechanism (Deleu et al. 2013, Wu et al. 2017).Interestingly, Gudiña et al. (2016) reported that the surfactin anticancer activity is in relation with its hydrophobic nature. In fact, the fatty acid moiety of surfactin strongly interacts with the acyl chain of the phospholipids in order to penetrate the outer sheet of lipid 
bilayer, while the peptide moiety interacts with the polar head group of the lipids in cancer cells.

\section{Conclusion}

390

In the present study, the best producing biosurfactant strain has been screened and selected.Termed B. safensis $\mathrm{F} 4$, it is a lipolytic bacterial strain that has the propriety to produce surfactin with important surface-active properties. Crude and purified biosurfactant showed important antibacterial activity under planktonic conditions, preventing also bacterial adherence through inhibiting early stage biofilmformation. Interestingly, surfactin from Bacillus sp. F4 haspotent cytotoxic activity against cancer cell lines,T47D breast cancer cells and B16F10 mouse melanoma cells. These findings make this studied surfactin a good candidate for potential applications in preventing infectious diseases and treating cancer.

\section{Acknowledgement}

The authors are grateful to Dr. Dorra Driss for her valuable critical reading of the manuscript. This work was funded by the Tunisian Ministry of Higher Education and Scientific Research.

\section{Conflict of interest}

The authors declare that they have no conflict of interest.

\section{References}

Alajlani M, Shiekh A, Hasnain S, Brantner A (2016) Purification of Bioactive Lipopeptides Produced by Bacillus subtilis Strain BIA. Chromatographia 79: 1527-1532. doi: $10.1007 / \mathrm{s} 10337-016-3164-3$

Arulselvan P, Fard MT, Tan WS, Gothai S, Fakurazi S, Norhaizan ME, Kumar SS (2016)

Role of Antioxidants and Natural Products in Inflammation. Oxid Med Cell Longev. doi:10.1155/2016/5276130 
Beenken KE, Blevins JS, Smeltzer MS (2003) Mutation of sarA in Staphylococcus aureus

411 limits biofilm formation. Infect Immun 71: 4206-4211. doi: 10.1128/IAI.71.7.4206-

412

413

414

415

416

417

418

419

420

421

422

423

424

425

426

427

428

429

430

431

432 4211.2003

Bezza FA, Chirwa EMN (2016) Pyrene Biodegradation Enhancement Potential of LipopeptideBiosurfactant Produced by Paenibacillusdendritiformis CN5 Strain. J Hazard Mater. doi:10.1016/j.jhazmat.2016.08.035

Cherif S, Mnif S, Hadrich F, Abdelkafi S, Sayadi S (2011) Strategy for improving extracellular lipolytic activities by a novel thermotolerant Staphylococcus sp. strain. Lipids Health Dis 10: 209- 216. doi:10.1186/1476-511X-10-209

Christova N, Lang S, Wray V, Kaloyanov K, Konstantinov S, Stoineva I (2015) Production, Structural Elucidation, and In Vitro Antitumor Activity of Trehalose Lipid Biosurfactant from Nocardiafarcinica Strain. J MicrobiolBiotechnol 25:439-447. doi: 10.4014/jmb.1406.06025

Colla LM, Rizzardi J, Pinto MH, Reinehr CO, Bertolin TE, Costa JA (2010) Simultaneous production of lipases and biosurfactants by submerged and solid-state bioprocesses. BioresourTechnol 101:8308-8314. doi:10.1016/j.biortech.2010.05.086

Cooper DG, Goldenberg BG (1987) Surface-Active Agents from Two Bacillus Species. Appl EnvironMicrob 53: 224-229

Das P, Mukherjee S, Sen R (2008) Antimicrobial potential of a lipopeptide biosurfactant derived from a marine B. circulans.J Appl Microbiol 104:1675-1684. doi: 10.1111/j.13652672.2007.03701.x

Deleu M, Lorent J, Lins L, Brasseur R, Braun N, El Kirat K, Nylander T, Dufrêne YF, Mingeot-Leclercq M-P (2013) Effects of surfactin on membrane models displaying lipid phase separation. BBA - Biomembranes 1828: 801-815. doi:10.1016/j.bbamem.2012.11.007 
433 Fernandes PA, Arruda IR, Santos AFA, Araújo AA, Maior AMS, Ximenes EA (2007)

434 Antimicrobial activity of surfactants produced by Bacillus subtilis R14 against multidrug435 resistant bacteria. Braz J Microbiol 38:704-709. doi: 10.1590/S1517-83822007000400022

436 Fiechteer A (1992) Biosurfactants: moving towards industrial application. Trends Biotechnol 437 10: 208- 217. doi: 10.1016/0167-7799(92)90215-H

438 Gargouri B, Contreras MM, Ammar S, Segura-Carretero A, Bouaziz M (2016) Biosurfactant 439 production by the crude oil degrading Stenotrophomonas sp. B-2: chemical characterization, 440 biological activities and environmental applications. Environ SciPollut Res24: 3769-3779. doi: 10.1007/s11356-016-8064-4

442 Ghazala I, Bouassida M, Krichen F, Benito JM, Ellouz-Chaabouni S, Haddar A (2017) 443 Anionic lipopeptides from Bacillus mojavensis I4 as effective antihypertensive agents: 444 Production, characterization, and identification. Eng Life Sci 0: 1-10. doi: $445 \quad 10.1002 /$ elsc.201700020

446 Girard L, Blanchet É , Intertaglia L, Baudart J, Stien D, Suzuki M, Lebaron P and Lami R 447 (2017) Characterization of N-Acyl Homoserine Lactones in Vibrio tasmaniensis LGP32 by a 448 Biosensor-Based UHPLC-HRMS/MS Method. Sensors 17: 906-918. doi: 10.3390/s17040906 449 Gudiña EJ, Teixeira JA, Rodrigue LR (2010a) Isolation and functional characterization of a 450 biosurfactant produced by Lactobacillus paracasei. Colloid Surface B 76: 298-304. doi: $451 \quad$ 10.1016/j.colsurfb.2009.11.008

452 Gudiña EJ, Rocha V, Teixeira JA, Rodrigues LR (2010b) Antimicrobial and antiadhesive 453 properties of a biosurfactant isolated from Lactobacillus paracaseissp. paracasei A20. Lett 454 Appl Microbiol 50 : 419-424. doi : 10.1111/j.1472-765X.2010.02818.x 
455 Gudiña EJ, Teixeira JA, Rodrigues LR (2016) Biosurfactants produced by marine 456 microorganisms with therapeutic applications. Mar Drugs 14: 38-52. doi: $457 \quad 10.3390 / \mathrm{md} 14020038$

458 Ibrahim HMM (2018) Characterization of biosurfactants produced by novel strains of 459 Ochrobactrumanthropi HM-1 and Citrobacterfreundii HM-2 from used engine oil460 contaminated soil. Egyptian Journal of Petroleum 27: 21-29. doi: 10.1016/j.ejpe.2016.12.005 461 Janek T, Łukaszewicz M, Rezanka T, Krasowska A (2010) Isolation and characterization of 462 two new lipopeptide biosurfactants produced by Pseudomonas fluorescens BD5 isolated from 463 water from the Arctic Archipelago of Svalbard. Bioresource Technol 101: 6118-6123. doi: 10.1016/j.biortech.2010.02.109

465 Janek T, Łukaszewicz M, Krasowska A (2013) Identification and characterization of 466 biosurfactants produced by the Arctic bacterium Pseudomonas putida BD2. Colloid Surface B 467 110: 379-386. doi: 10.1016/j.colsurfb.2013.05.008

468 Jardak M, Abdelli F, Laadhar R, Lami R, Stien D, Aifa S, Mnif S (2017) Evaluation of 469 biofilm-forming ability of bacterial strains isolated from the roof of an old house. J Gen Appl 470 Microbiol 63: 186-194. doi: 10.2323/jgam.2016.10.005

471 Jasim B, Sreelakshmi KS, Mathew J, Radhakrishnan EK (2016) Surfactin, Iturin, and 472 Fengycin Biosynthesis by Endophytic Bacillus sp. from Bacopamonnieri. MicrobEcol 72: 473 106-119. doi: 10.1007/s00248-016-0753-5

474 Jemil N, Ben Ayed H, Hmidet N, Nasri M (2016) Characterization and properties of 475 biosurfactants produced by a newly isolated strain Bacillus methylotrophicus DCS1 and their 476 applications in enhancing solubility of hydrocarbon.World J MicrobiolBiotechnol 32:175477 187.doi 10.1007/s11274-016-2132-2 
478 Jemil N, Ben AyedH , Manresa A, Nasri M, Hmidet N (2017) Antioxidant properties, 479 antimicrobial and anti-adhesive activities of DCS1 lipopeptides from Bacillus 480 methylotrophicus DCS1. BMC Microbiol 17:144-154.doi :10.1186/s12866-017-1050-2

481

482

Mathur T, Singhal S, Khan S, Upadhyay DJ, Fatma T, Rattan A (2006) Detection of biofilm formation among the clinical isolates of staphylococci: an evaluation of three different screening methods. Indian J MedMicrobi. 24: 25-29. doi: 10.4103/0255-0857.19890

Merghni A, Dallel I, Noumi E, Kadmi Y, Hentati H , Tobji S, Ben Amor A , Mastouri M (2017) Antioxidant and antiproliferative potential of biosurfactants isolated from Lactobacillus casei and their anti-biofilm effect in oral Staphylococcus aureus strains. MicrobPathog 104: 84-89. doi: 10.1016/j.micpath.2017.01.017

Morikawa M, Daido H, Takao T, Murata S, Shimonishi Y, Imanaka T (1993) A new lipopeptide biosurfactant produced by Arthrobacter sp. strain MIS38. J Bacteriol 175: 64596466. doi: 10.1128/jb.175.20.6459-6466.1993

Moryl M, Spętana M, Dziubek K, Paraszkiewicz K, Różalska S, Płaza GA, Różalski A (2015) Antimicrobial, antiadhesive and antibiofilm potential of lipopeptidessynthesised by Bacillus subtilis, on uropathogenic bacteria. ActaBiochimPol62:725-732.doi: 10.18388/abp.2015_1120

MosmannT (1983) Rapid colorimetric assay for cellular growth and survival: application to proliferation and cytotoxicity assays. J Immunol Methods 65: 55-63. doi: 10.1016/00221759(83)90303-4

Nagai T, Arai Y, Emori M , Nunome S, Yabe T, Takeda T, Yamada H (2004) Anti-allergic activity of a Kampo (Japanese herbal) medicine "Sho-seiryu-to (Xiao-Qing-Long-Tang)" on airway inflammation in a mouse model. IntImmunopharmacol 4:1353 -1365. doi: 10.1016/j.intimp.2004.05.021 
Naruya S, Nei M (1987) The neighbor-joining method: a new method for reconstructing phylogenetic trees. MolBiolEvol 4: 406-425. doi: 10.1093/oxfordjournals.molbev.a040454

Padmavathi AR, Pandian SK (2014) Antibiofilm activity of biosurfactant producing coral associated bacteria isolated from Gulf of Mannar, IndianJ Microbiol 54: 376-382. Doi: $10.1007 / \mathrm{s} 12088-014-0474-8$

Price NPJ, Rooney AP, Swezey JL, Perry E, Cohan FM (2007) Mass spectrometric analysis of lipopeptides from Bacillus strains isolated from diverse geographical locations. FEMS Microbiol Lett 271: 83-89. doi: 10.1111/j.1574-6968.2007.00702.x

Rodrigues L, Banat IM, Vandermis HC, Teixeira JA, Oliveira R (2006a) Interference in adhesion of bacteria and yeasts isolated from explanted voice prostheses to silicone rubber by rhamnolipid biosurfactants. J Appl Microbiol 100: 470-480. doi:10.1111/j.13652672.2005.02826.x

Rodrigues L, Banat IM, Teixeira J, Oliveira R (2006b) Biosurfactants: potential applications in medicine. J AntimicrobChemother 57: 609-618. doi: 10.1093/jac/dk1024

Sambanthamoorthy K, Feng X, Patel R, Patel S, Paranavitana C (2014) Antimicrobial and antibiofilm potential of biosurfactants isolated from lactobacilli against multi drug resistant pathogens. BMC Microbiol 14: 197- 205. doi: 10.1186/1471-2180-14-197

SekhonKK, Khanna S, Cameotra SS (2011) Enhanced biosurfactant production through cloning of three genes and role of esterase in biosurfactant release. Microb Cell Fact 10: 4958. doi: $10.1186 / 1475-2859-10-49$

Sekhon KK, Khanna S, Cameotra SS (2012) Biosurfactant Production and Potential Correlation with Esterase Activity. J Pet EnvironBiotechnol 3: 7- 16. doi: 10.4172/21577463.1000133 
525 Sharma D, Saharan BS (2016) Functional characterization of biomedical potential of 526 biosurfactant produced by Lactobacillus helveticus. Biotechnology Reports 11: 27-35. doi:

527

528

529

530

531

532

533

534

535

536

537

538

539

540

541

542

543

544

545

546

547

548 10.1016/j.btre.2016.05.001

Sen S, Borah SN, Bora A, Deka S (2017) Production, characterization, and antifungal activity of a biosurfactant produced by Rhodotorulababjevae YS3. Microb Cell Fact 16:95108. doi: 10.1186/s12934-017-0711-z

Shete AM,Wadhawa G, Banat IM, Chopade BA (2006) Mapping of patents on bioemulsifier and biosurfactant: A review. J Sci Ind Res 65: 91-115.

Silva NRA, Luna MAC, Santiago ALCMA, Franco LO,Silva GKB, Souza PM, Okada K, Albuquerque CDC, Silva CAA, Takaki GMC (2014) Biosurfactant-and-bioemulsifier produced by a promising Cunninghamellaechinulata isolated from Caatinga soil in the northeast of Brazil. Int J Mol Sci 15:15377-15395. doi: 10.3390/ijms150915377

Singh P, Cameotra SS (2004) Potential applications of microbial surfactants in biomedical sciences. Trends

Biotechnol22:142-146.

Doi:10.1016/j.tibtech.2004.01.010

Sriram MI, Kalishwaralal K, Deepak V, Gracerosepat R, Srisakthi K, Gurunathan S (2011)

Biofilm inhibition and antimicrobial action of lipopeptide biosurfactant produced by heavy metal tolerant strain Bacillus cereus NK1. Coll Surf B 85:174-181. doi: 10.1016/j.colsurfb.2011.02.026

Ülker S, Karaoglu S A (2012) Purification and characterization of an extracellular lipase from Mucorhiemalis f. corticola isolated from soil. J BiosciBioeng 114:385-390. Doi: 10.1016/j.jbiosc.2012.04.023

Vasudevan P, Nair M K, Annamalai T, Venkitanarayanan K S (2003) Phenotypic and genotypic characterization of bovine mastitis isolates of Staphylococcus aureus for biofilm formation. Vet Microbiol 92:179-185. doi: 10.1016/S0378-1135(02)00360-7 
549 Vollenbroich D, Pauli G, Ozel M, Vater J (1997) Antimycoplasma Properties and Application

550 in Cell Culture of Surfactin, a Lipopeptide Antibiotic from Bacillus subtilis. Appl Environ

551 Microb 63: 44-49

552 Wilson K (1987) Preparation of genomic DNA from bacteria, in Ausubel F M, Brent R,

553 Kingston R E, Moore D D, Seidman J G, Smith J A, Struhl K (ed.), Current protocols in

554 molecular biology, John Wiley and Sons, New York, 2003, p2.4.1.-2.4.2

555 Wu YS, Ngai SC, Goh BH, Chan KG, Lee LH, Chuah LH (2017) Anticancer Activities of 556 Surfactin and Potential Application of Nanotechnology Assisted Surfactin Delivery. Front.

557 Pharmacol 8:761. doi: 10.3389/fphar.2017.00761

558 Yakimov MM, Timmis KN, Golyshin PN (2007) Obligate oil-degrading marine bacteria.

559 CurrOpin Biotech 18: 257-266. doi: 10.1016/j.copbio.2007.04.006

560 Zhao H, Shao D, Jiang C, Shi J, Li Q, Huang Q, Rajoka MSR, Yang H, Jin M (2017)

561 Biological activity of lipopeptides from Bacillus. ApplMicrobiolBiotechnol 101: 5951-5960.

562 doi: 10.1007/s00253-017-8396-0

563

564

565 